\title{
DIÁRIO DO FUTURO
}

DIARY OF THE FUTURE

Priscilla Campos

Priscilla Campos nasceu no Recife. É jornalista, crítica literária, poeta e doutoranda em Literatura Hispano-Americana pela Unipoeta e doutoranda em LiUSP). Publicou, em poesia, o pesto (nsostros editorial) e, em formato ensaio, Nenhum muro à altura do peito (Edições Macondo).

priscillaopcampos@gmail.com 


\section{MULHER DE FAMÍLIA}

tenho lavado as mãos com água fria, torneiras não funcionam como antes e as partes mais altas dos edifícios começam a pender para os lados. eu sinto receio que os moradores ta mbém comecem a viver um pouco tortos um pouco elásticos, imagina os talheres todos juntinhos de um único lado da cozinha

imagina eu e você contando os passos em direção ao quarto porque agora num trecho do caminho nós vamos enga tinhar a té a cama e quando deitados já não sei em que lado do beijo eu fico ou qual a melhor perspectiva para que eu veja os seus braços livres te observar em movimento será sempre alterado pela envergadura das janelas

vamos aprender também a tecer outro membro como as caudas dos escorpiões: perder-se em fuga para retornar em veneno e talvez assim seja possível continuar a quase cair pela casa, não sentir falta da potência das torneiras, luísa tem os olhos da sua tia e me pergunta o porquê de enxergar tudo meio em "ca mbalhota" - mãe eu vejo você no chão e no teto ao mesmo tempo

eu dou risada e engatinho mais rápido, te peço que mais tarde por favor equilibre a sua mão na minha bunda da maneira que você desejar 


\section{CETUS GALAXIES AND SUPERNOVA}

são sessenta e quatro corpos simples que compõem o nosso cosmo, substâncias consideradas irredutíveis algumas menos importantes do que outras como a cor da sua parede é menos importante do que o funcionamento dos aviões ou do que os motores dos navios rioplatenses

os corpos simples existem no globo em proporções desiguais são os cálculos de densidade que variam e então vemos uma espécie de bala nça do que vai resistir à gravidade ou não do que vai iluminar as ruas de Almagro ou do Bom Retiro e quem retribui em calor na sua tarde de domingo ou na minha cama na manhã de terça-feira

nem todos os corpos simples estão no espectro solar alguns estão às margens do sistema ocultos de tantas maneiras a nós os que caminhamos na América do Sul e temos as noites mais abertas do mundo; e no que se faz vasto eu lembro dos cometas - massas atravessam os céus para então sumir não encontradas mesmo qua ndo vistas o sumiço mesmo qua ndo se brilha, armadilhas das zonas pla netárias

me conforta os meus olhos de terra partida quando te observo desenhando mapas sorriso desa tado como a noite equilibrando as proporções dos sessenta e quatro. e ali, na margem do espectro, tão longe das minhas mãos que continuam próximas às ja nelas você nada nos aquários embaixo dos móveis de todas as casas que habito

mais violento do que qualquer decolagem

e quente como o último cometa que esta Terra recebeu 